\title{
Multiple Aneurysms Associated with Agenesis of Internal Carotid Artery
}

\author{
Internal Karotid Arter Anevrizması ile İlişkili Çoklu Anevrizma Olgusu
}

\author{
Abrar WANI, Sanjay BEHARI, Bernard LYNDOH, Awdesh JAISWAL, RN SAHU, VK JAIN \\ Department of Neurosurgery, Sanjay Gandhi Postgraduate Institute of Medical Sciences, Lucknow, India
}

Correspondence address: AbrarWANI / E-mail: abrarwani@rediffmail.com

\begin{abstract}
Agenesis of internal carotid artery (ICA) is a rare anomaly. The contralateral dominant artery has a high incidence of aneurysms. A 50-year-old male patient had aneurysmal subarachnoid hemorrhage due to rupture of a paraclinoid aneurysm. He also had an anterior communicating artery (Acom) aneurysm and the contralateral ICA was absent. To the best of the authors knowledge, the combination of agenesis of unilateral internal carotid artery with the unique association of a paraclinoid and an Acom aneurysm has not been previously reported. A meticulous assessment of the collateral blood circulation prior to surgery is mandatory in these cases for avoiding postoperative ischemic injury.
\end{abstract}

KEYWORDS: Agenesis, Aneurysm, Subarachnoid hemorrhage

öz

Internal karotid arter agenesisi nadir görülen bir anomalidir. Bu gibi patolojilerde karşı taraf baskın arterlerde anevrizma görülme sıklığı artmıştır. Elli yaşında erkek hasta paraklinoid anevrizma rüptürüne bağlı subaraknoid kanama nedeni ile tedaviye alındı. Angiografik incelemede hastada anterior komünikan arter anevrizması ile birlikte karşı taraf internal karotid arter agenesisi tesbit edildi. Bizim bilgimize göre tek taraflı internal karotid arter agenesisi ile birlikte seyreden anterior komünikan arter ve paraklinoid anevrizma olgusu ilk kez rapor edilmektedir. Kollateral kan dolaşımının durumunun ortaya konması ameliyat sonrası oluşabilecek iskemik hasarın önlenmesi için temel ve zorunlu bir işlemdir.

ANAHTAR SÖZCÜKLER: Agenezi, Anevrizma, Subaraknoid kanama

\section{INTRODUCTION}

Congenital absence of ICA is a rare anomaly with approximately 100 cases reported in the world literature $(7,3)$. The existence of this anomaly results in unique management problems. The development of collaterals from the contralateral side may not be adequate to support the circulation of the involved hemisphere. The high hemodynamic stress on the dominant contralateral ICA may result in a high incidence of aneurysm formation ranging from $24 \%$ to $34 \%$ (10). The unique combination of agenesis of the left ICA, the complete support of anterior circulation by the dominant right ICA and the co-existence of a paraclinoid aneurysm on the right side and an Acom aneurysm seen in this case has not been reported before.

\section{CASE REPORT}

A 48-year-old male, a known hypertensive on irregular medication, presented with sudden onset of severe headache with vomiting and transient loss of consciousness. He was referred to our centre on the third day following ictus in Hunt \& Hess grade I. His CT scan revealed subarachnoid hemorrhage in the suprasellar cistern, interhemispheric fissure and bilateral sylvian fissures. The digital subtraction angiogram (DSA) revealed non-visualization of left ICA. The ICA could not be identified on the left side during angiography so a common carotid artery injection was done (Figure 1A). The contrast filled the external carotid artery and its branches (Figure 1B), while the left ICA could not be visualized. The right ICA showed dominant circulation with filling of the bilateral anterior cerebral arteries (ACA) and middle cerebral arteries (MCA) through the anterior communicating artery (Acom) (Figure 2). A large paraclinoid aneurysm was present on the right ICA. An additional Acom artery aneurysm was also present. (Figure 2).The left vertebral injection revealed filling of the MCA from the left posterior communicating artery (Pcom) (Figure 3). The patient was operated using a right pterional transsylvian approach and the Acom aneurysm was clipped. The anterior clinoid was then drilled and the right ICA mobilized after cutting the distal dural ring. The ICA paraclinoid aneurysm was clipped using a fenestrated clip that took the ICA in its fenestration. The patient had no neurological deficits following surgery.

\section{DISCUSSION}

The development of the common carotid artery and internal carotid artery has been a subject of controversy (4). Padget did an extensive study on the subject. Specific cranial vessels can be identified at $3 \mathrm{~mm}$ crown-rump length of the fetus. 

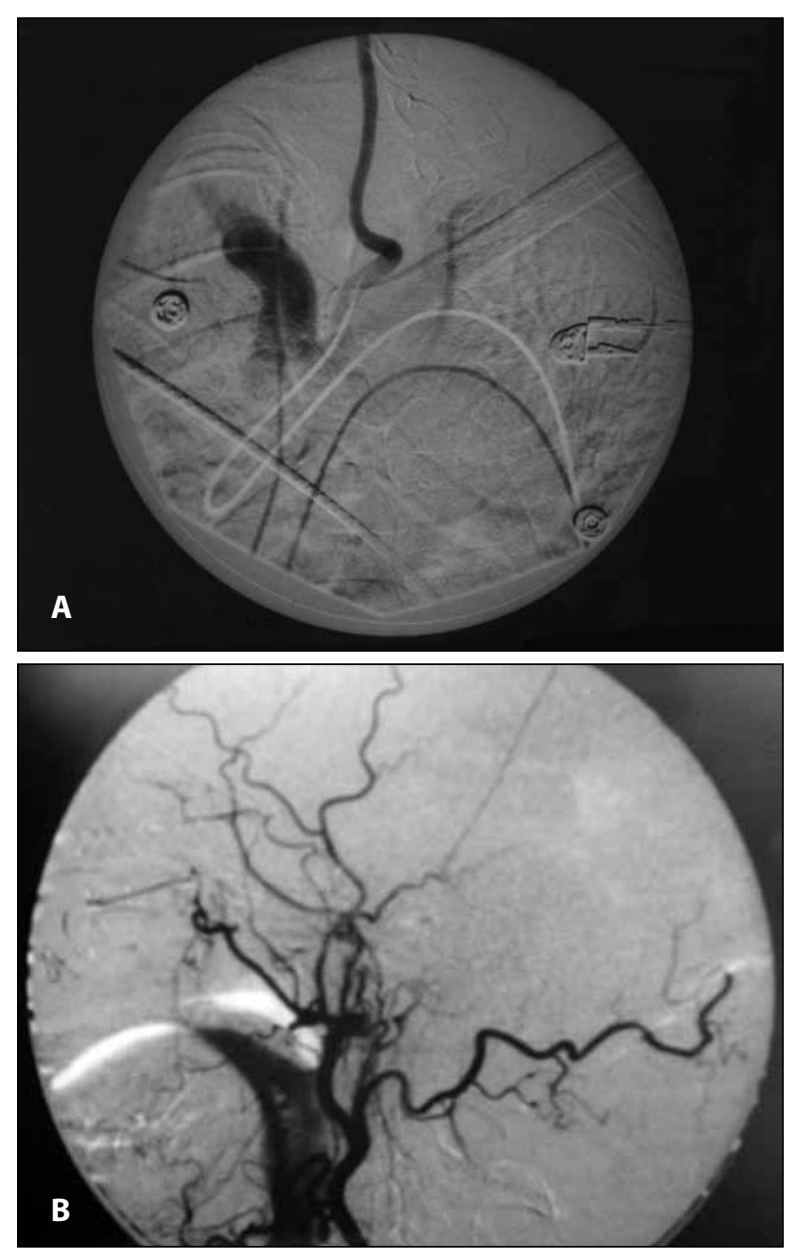

Figure 1: A) The right CCA been canulated and the ICA not identified; B) Right CCA injection showing filling of ECA branches and non-visualization of the ICA.

The ICA form as branches from first aortic arches. By the 4 $\mathrm{mm}$ stage, the first and second aortic arches regress and the internal carotids become continuous with the third aortic arches, which serve as their roots. At the same time, a pair of vessels called the longitudinal neural arteries develop at the base of the hindbrain, dorsal and parallel to the ICA. A communication develops between the longitudinal neural arteries and the caudal branch of ICA, which forms the posterior communicating artery (6).

Agenesis of internal carotid artery was first reported in 1787 (5). An absent ICA was first demonstrated on cerebral angiography in 1954 (2). Varying degrees of embryonic insults can lead to absence of ICA, but the exact sequence of events leading to this anomaly is still unknown (9). This entity is associated with a high incidence of aneurysms on the contralateral dominant side as was seen in our case (10). Cali et al showed that the pattern of collateral blood flow to distal ACA and its branches depended on the stage at which disturbance had occurred in case of an absent ICA (1). His postulation was that primitive pathways of

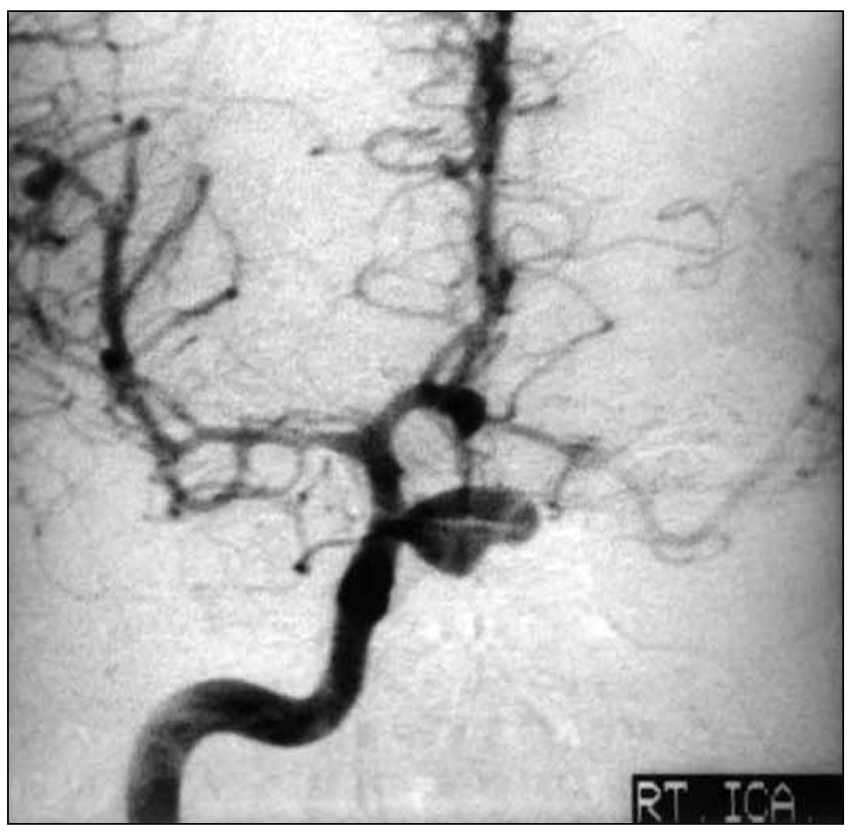

Figure 2: Left CCA injection showing aneurysms arising from the paraclinoid portion of the left ICA and other aneurysm arising from the Acom.

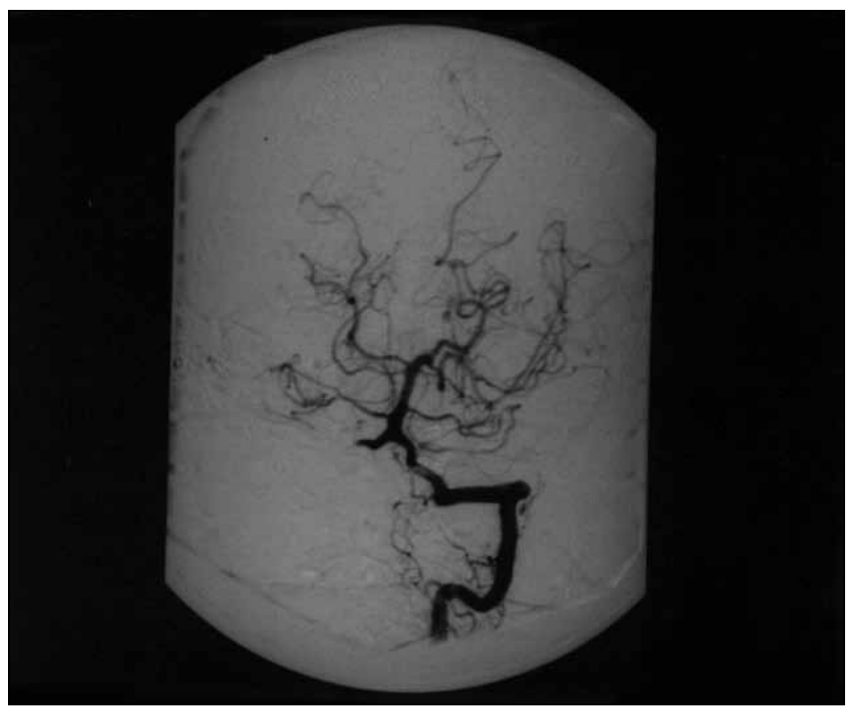

Figure 3: Left vertebral injection showing filling of the left MCA from the left posterior communicating artery.

collateral circulation prevail if the disruption occurred before completion of the circle of Willis. Collateral flow would occur through circle of Willis if disruption occurred after the $24 \mathrm{~mm}$ stage of development. In our patient, the collateral pathway to the region that would normally have been supplied by absent ICA was maintained through contralateral supply via Acom and ipsilateral vertebrobasilar circulation through the posterior communicating artery. Thus, the embryologic insult possibly occurred after the $24 \mathrm{~mm}$ stage as no primitive pathway was evident in our patient. Lie described six ways a collateral circulation is established in case of absent ICA (4). 
In type $A$, the ipsilateral ACA is supplied by a patent Acom and MCA is supplied directly by the hypertrophied posterior communicating artery (Pcom). In type $B$, the ipsilateral ACA and MCA are supplied by the Acom. In type $C$, there is bilateral absence of ICA and the anterior circulation is supplied by posterior circulation through bilateral Pcom. In type $D$, there is unilateral agenesis of the cervical portions of the ICA and blood supply is by the intercavernous communication between the two carotid siphons. In type E, bilateral ACAs are supplied by hypoplastic ICAs and bilateral MCAs are supplied by enlarged Pcoms. In type F, collateral flow to distal ICA is via the internal maxillary branches of the external carotid artery. Our case conformed to type A of Lie's classification as the MCA in our case was receiving supply from both the Pcom and Acom. The congenital absence may be unilateral or bilateral but the former is more common (8), and there is predilection for left-sided absence with a ratio of 3:1 as was seen in our case (3). The increased turbulence and shearing stress in the dominant contralateral ICA that was supporting bilateral anterior circulation was responsible for the development of two aneurysms. However, a common etiology like an intrinsic defect in the vessel wall formation may be responsible both for development of aneurysms and agenesis of the ICA. We were fortunate that both the aneurysms could be clipped without any temporary clipping and also that there was no vasospasm in the dominant ICA, hence obviating the risk of global ischemia in our patient.

\section{REFERENCES}

1. Cali RI, Berg R, Rama K: Bilateral internal carotid agenesis: A case study and review of the literature. Surgery 13: 227-233,1993

2. Claros P, Bandos R, Gilea I, et al: Case report: Major congenital anomalies of the internal carotid artery with - agenesis, aplasia, and hypoplasia. Int J Pediatric Otorhinolaryngol 49: 69-76,1999

3. Curtis A, Given II, Frank Huang - Hellinger, Michael D, Baker, Neeraj B, Chepuri and P Pearse morris: Congenital absence of the internal carotid artery: Case reports and review of the collateral circulation. AJNR Am J Neuroradiol 22: 1953-1959, 2001

4. Lie TA: Congenital anomalies of the carotid arteries. Amsterdam: Excerpta Medica: 35-51,1968

5. Midkiff RB, Boykin MW, McFarland DR,Bauman JA: Agenesis of the internal carotid artery with intercavernous anastomosis.AJNR Am J Neuroradiol $16: 1356-1359,1995$

6. Padget $\mathrm{DH}$ : The development of the cranial arteries in the human embryo. Contrib Embryol 32: 207-262, 1948

7. Quint DJ, Boulos RS, Spera TD: Congenital absence of the cervical and petrous internal carotid artery with intercavernous anastomosis. AJNR An J Neuroradiol 10 : 435-439, 1989

8. Teal JS, Naheedy MH, Hasso AN: Total agenesis of the internal carotid artery. AJNR Am J Neuroradiol 1: 435-442, 1980

9. Teal JS, Rumbaugh CL, Bergeron RT, Segall HD: Congenital absence of the internal carotid artery associated with cerebral hemiatrophy, absence of the external carotid artery, and persistence of the stapedial artery.AJR Am J Roentgenol 118: 534-544,1973

10. Toru Serizawa, Naokatsu Saeki, Akira Yamaura: Microsurgical anatomy and clinical significance of the anterior communicating artery and its perforating branches. Neurosurgery 40: 1211-1218, 1997 